\title{
Interview with contemporary Siberian philosopher Fyodor Girenok
}

\author{
FYODOR GIRENOK IN CONVERSATION WITH SLOVO'S EXECUTIVE EDITOR EUGENIA \\ ELLANSKAYA \\ Moscow State University (Faculty of Philosophy) and UCL School of Slavonic and East \\ European Studies
}

Fyodor Girenok is a Professor of Philosophical Anthropology at Moscow State University. He is the leader and founder of the cutting-edge Russian philosophical movement known as archaeoavantgarde and is one of the most notable Russian philosophers of today. Girenok's books and articles have been extensively published in Russia, exploring such topics as language, speech, and inter-human communication. Focusing on philosophical anthropology, Girenok's works address the metaphysics and phenomenology of the human condition and the issues of the crucial relationship with the Other. As well as an innovative thinker in his own right, Girenok provides ingenious discussions of the classical philosophical concepts and debates evoked by Plato, Descartes, Kant, and Hegel, as well as the anthropological ideas of Husserl, Lacan, Foucault, Sartre, and Deleuze. The movement of archaeo-avantgarde is akin to Western postmodernism and considers the past as something to be decoded by avant-garde philosophical thinking. His works (at the moment only available in Russian) are remarkable for the digestible poetic organization of the text itself and for the approachability of the complex discussions evoked. Girenok is a philosopher to be reckoned with, proposing fundamentally new ways of thinking and communicating. As Fyodor's works remain unpublished in English as of yet, Slovo is introducing to the English-speaking readers a Siberian philosopher that makes a difference.

\section{SLOVO: Who were your childhood "heroes"? Who would you say shaped your philosophy growing up?}

FYODOR: As a child my hero was Karl Marx. I read the first volume of his Das Kapital when I was 12. At 25 I really got into the Russian philosophers Evald Il'yenkov, Georgii Shchedrovitskii and Merab Mamardashvili. They were all Marxists, but each in their own way: Mamardashvili as an existentialist, Il'yenkov as a Hegelian, and Shchedrovitsky as an educationalist. Then later I discovered Boris Porshnev, Nicholas Marr and Yurii Borodai.

SLOVO: In Russia you are known for coining the philosophical term 'archaeoavantgarde'. You identify yourself accordingly as an 'archaeo-avantgardist'. What is archaeo-avantgarde? How is this complex-sounding term different from the familiar concept of postmodernism?

FYODOR: Postmodernism assumes that a thought can be thought irrespectively of what a man thinks. Archaeo-avantgarde assumes otherwise. It thinks thoughts in relation to what a man thinks. Postmodernism exaggerates the role of language. It 
thinks of the world in terms of language. Archaeo-avantgarde acknowledges the limits of language in our consciousness. It sees emotion as an explosion of hallucinations equivalent to the Big Bang in physics. But there's more.

Notice the way the word 'archaeo-avantgarde' is constructed: it combines the past (i.e. archaeo) and the future (i.e. avant-garde). But there is no present. So what happened to the present? Who or what has consumed it? For we know that time has past, present and future tenses. We also know that time flows: either from the past into the future (via the present), or from the future into the past.

Archaeo-avantgarde does not follow Bergson, Heidegger, and Husserl in its understanding of time. As archaeo-avantgardists we reform the concept of time. What for? In order to discover new means of understanding time, the means which aren't available if one considers time as something flowing. Time does not flow to, or from, anywhere. Look at children - they pay no attention to time up to a certain age. They are situated in a continuously lasting present tense, in a time which knows no change of states. So a human can well do with the present tense alone, with no past or future. Time as a constantly lasting present tense does not rely on notions of truth or reality. Time understood as flow, on the other hand, is all used up by various schemes of reality.

Things become radically different when language gets involved. Language and consciousness are enemies. The first thing language does is elimination of the present. It turns it to zero, into something that isn't. Instead of the present there emerges a past and an unrelated future.

Language brings our consciousness out into the future and forces it to look back on itself in the past. History is then a product of self-reflection, something that needs constant rewriting. There is no objective history. Preoccupation with the future is an act of self-deception. An appeal to the memory of the past is a language game. Archaeo-avantgarde enters into all this as an attempt to connect the past and the present by avoiding language.

Being is one of the most fundamental notions of Western philosophy. Archaeoavantgarde acknowledges the fact that ontology [as the theory of Being] and anthropology are at constant war with each other. For we cannot speak of Being as something that had been. Similarly we cannot speak of it as something that will be. It always is.

Where a human is concerned, on the other hand, we can speak of him as someone who had been or as someone who will be. But a human never is. Because he exists only as an inclination to become someone else, to not be what he is. The Lantern of 
Diogenes is a symbol of this absence of man in the present [Diogenes - an ancient Greek, known to have fruitlessly wandered in search of an honest man].

SLOVO: Today the biggest enemy of knowledge is paradoxically the excess of information. Information is available to everyone from everywhere. The act of knowing, and getting satisfaction from knowledge in this environment of informational noise, has become increasingly difficult. What is your take on this? How would you recommend dealing with it?

FYODOR: I would like to draw attention to Heidegger's concluding words in his Nietzsche's Word God is dead.

Heidegger says that reason is an irreconcilable enemy of thinking. Why? Possibly because reason is about calculating, and thinking is about daydreaming.

The key event of the end of the $20^{\text {th }}$ century is to do with language's substitution of consciousness. As soon as this happened, virtually nothing humane remained in humans. Consciousness is a traumatic act upon the self, while language is just empty form. The early $21^{\text {st }}$ century philosophy suddenly realized that reason (intellect) should be distinguished from consciousness. Intellect has nothing to do with consciousness. To be thinking is not to be intelligent, and to be intelligent is not to be thinking. The modern world has become too full of knowledge, while lacking in consciousness. People no longer enjoy thinking. In order to gain pleasure from thinking consciousness needs to come back into it. Then one can not only take in the words said, but also those that are under-said and over-said.

SLOVO: In the Russian film Udovol'stvie myslit' inache ['The joy of thinking otherwise'] by Mark Ditkovskii you speak of philosophy's reluctance to think, i.e., to perform its main function. The film covers the problem of recycling secondhand philosophical ideas, creating a crisis of philosophy, its morbid decay. You mention how philosophy enjoys sitting in its comfort zone in libraries and cosy armchairs while at the same time demanding great energy expenditure to understand things that really aren't that new. It stops being interesting and poignant, I agree with you. How would you formulate the main goals and approaches of cutting edge modern philosophy which would meet its purpose?

FYODOR: I think modern philosophy changes the meaning of what it is to be "intelligent". To be intelligent often means to be obedient, obedient to the Other. The intellect within us is desired by the Other. The Other nurtures, brings up and cultivates this intellect in us. The motto of modern philosophy is 'don't be obedient', 'be irrational' - this is what makes the impossible possible.

Moreover modern philosophy seems to come to a realisation that consciousness is something that makes you blush, something that causes one to "self-harm", 
something that bothers you. Consciousness stings and bites the Self. Well, it all means that a human is not an intelligent but a thinking being.

SLOVO: We are very intrigued by your use of the term "autism" [in discussions on Selfhood]. What is it about this term that makes it important for your philosophy? Could we say that your use of the term autism represents the most desirable state of being, a breakthrough in thinking and knowing of the Self?

FYODOR: First of all, I'd like to clarify that autism does not interest me as much in its medical use, but first and foremost as a philosophical term. The concepts of apathy, ataraxia, scepticism and peace were formulated by the philosophy of antiquity; the concept of nirvana was coined by Oriental philosophy. Autism is another such term. It lets us think of what it is to be human independently of the Other, independently of communication and language. In a state of autism a man hovers between two substances: nature and society. This man has nothing that was given to him by either nature or society. Nature has not given him intellect as an instinct, while society has not given him language as a means of uniting with the Other. All he can get, he gets by self-limitation. Autism teaches us that a daydreamer can either get nothing, or not get all.

But an autistic thinker can get the main thing: to stop speaking the language of the Other and use his own language, from his own Self. In order to speak from one's own name, one needs to meet the Self. Autism is what everyone has to go through in order to access the Self.

SLOVO: To continue with the fundamental concepts of your philosophy... You often speak of the role of emotion. Many would probably be surprised at this emphasis on the irrational component of our humanity. Why is emotion important?

FYODOR: Not reason, but emotion is the hallmark of humanity. To the extent in which we are capable to act upon ourselves, bringing ourselves to a state of following sameness, we are not elements of nature or elements of society. We are contemplators of the human domain in the world. Emotion is the last inalienable territory of humanity. I'd like to note that French postmodernism has given up this territory to cosmic energy and universal structures.

SLOVO: Based on your book Absurd $i$ Rech [Absurd and Speech], can we say that emotion, then, comes into the Absurd events, which you see as key to the development of man?

FYODOR: A human is always an outcome of the world's failure to lean away from encountering the Absurd. Every man is branded by the traces of his encounter with the impossible. Reason abdicates before the absurd. 
SLOVO: Your writing style in Russian is remarkably visual. The text is notably divided into compact digestible sections. Such texts are quite different from the cryptic and dense philosophical passages that many would be familiar with. What should a $21^{\text {st }}$ century text be like to remain interesting and impactful?

FYODOR: A text should be brief. I must be able to read it in between train stops. It should have nothing excessive. It should be a conceptual letter. Text should also captivate and entertain. It has to be a piece of literature. One metaphor can be worth more than an essay of many pages.

SLOVO: It seems that one such recurrent metaphor in your own texts is that of God. In an age of secular sermons (e.g., Alain de Botton's School of Life) and attempts to find an alternative morality without God, you continue to mention God in your works. To what extent is God just a metaphor for you, and why is God important?

FYODOR: I do not believe in morality without God. For me God emerges when you need to make a choice between two opposable actions, while there are no guiding reasons to make this choice. They will appear later in the next step when norms and laws come into play. God here is a primordial limitation, a limitation of the first step of decision-making.

SLOVO: This is a lot to take in. Thank you so much for agreeing to share your thoughts with Slovo. We hope that one day we will have access to more of these ideas when your books become available to the English readers. To conclude I would like to ask you to define yourself as a philosopher for our readers.

FYODOR: I give words [slovo] to the pre-verbal [doslovnoe], I give my voice to voicelessness.

I am a philosopher of the preverbal.

This work is licensed under the Creative Commons Attribution-Non-commercial-Share-alike 2.0 UK: England \& Wales License. This license allows for redistribution and alteration, commercial and non-commercial, as long as credit is given to the author. To view a full copy of this license, visit: http://creativecommons.org/licenses/ or send a letter to Creative Commons, 444 Castro Street, Suite 900, Mountain View. 